\title{
Social Vulnerability and How It Matters: A Bibliometric Analysis
}

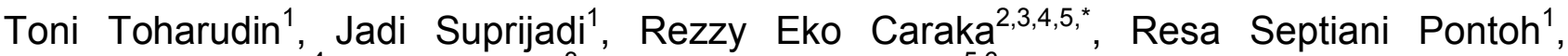 \\ Rung Ching Chen ${ }^{4}$, Youngjo Lee ${ }^{3}$ and Bens Pardamean ${ }^{5,6}$
}

\begin{abstract}
${ }^{1}$ Department of Statistics, Faculty of Mathematics and Natural Science, Universitas Padjadjaran, Bandung 45363, Indonesia

${ }^{2}$ College of Medicine, Seoul National University, 103 Daehak-ro, Ihwa-dong, Jongno-gu, Seoul, Republic of Korea

${ }^{3}$ Laboratory Hierarchical Likelihood, Department of Statistics, College of Natural Science, Seoul National University, Seoul 08826, South Korea

${ }^{4}$ Department of Information Management, College of Informatics, Chaoyang University of Technology, Taichung City 41349, Taiwan

${ }^{5}$ Bioinformatics and Data Science Research Center, Bina Nusantara University, Jakarta 11480, Indonesia

${ }^{6}$ BINUS Graduate Program- Master of Computer Science Program, Bina Nusantara University, Jakarta, 11480, Indonesia
\end{abstract}

\begin{abstract}
Interdisciplinary and cross-cultural studies of the impacts of environment and social vulnerability must be undertaken to address the problem of social vulnerability in the foreseeable future. Scientist or social scientists should first continuously strive towards approaches can integrate municipal technological expertise, experiences, knowledge, perceptions, and expectations into emergency circumstances, so that people can be sharper on issues and offer responses with their matters. In this paper. We performing the Bibliometric Analysis to review published papers on the keyword 'Social Vulnerability'. There are 29,468 papers published in the last 52 years from 1969 to November 2020. Disaster research by implementing the Internet of Things (IoT), data mining, machine learning is still needed.
\end{abstract}

Keywords: Social Vulnerability, Review, Bibliometric, Disaster, Mitigation.

\section{INTRODUCTION}

The disasters that have occurred during the last few years have made both developed countries and developing countries quite progressive in disaster management in the future. The workable steps include issuing state policies and applying technology that is so advanced and massive. The essence of disaster risk reduction is building the resilience of countries and communities to disasters. In principle, vulnerability analysis is used as a diagnostic tool to understand the problems and factors that cause vulnerability, a planning tool as a basis for prioritizing activities and a sequence of planned activities, a risk measurement tool to assess specific risks, and a tool for empowering and mobilizing community groups. Meanwhile, the vulnerability analysis is a part of risk analysis that enables disaster management stakeholders to manage disaster risk. The components and indicators of vulnerability are derived from the concepts, definitions, and factors that determine vulnerability. Turner et al.,

*Address correspondence to this author at the Laboratory Hierarchical Likelihood, Department of Statistics, College of Natural Science, Seoul National University, Seoul 08826, South Korea; Tel: +82 2880 6568; Fax: +82

2883 6144; E-mail: rezzy94@snu.ac.kr
(2003) address the question "Who and what is vulnerable to the multiple environmental changes underway, and where? Research demonstrates that vulnerability is registered not by exposure to hazards (perturbations and stresses) alone but also resides in the sensitivity and resilience of the system experiencing such hazards?" At this time, there are variations in the definition of vulnerability which will impact various indicators and instruments of vulnerability (Carreño, Cardona, and Barbat, 2007). Likewise, the components are extended to include physical and environmental vulnerabilities (Siagian et al., 2014). Social experts agree on several main factors that affect social vulnerability (Kaban et al., 2019; Nasution et al., 2020) including lack of access to resources including information (Quarantelli, 1988), knowledge, and technology (Pathirage et al., 2012), limited access to political power and representation (Drake, 2016), social capital (Aldrich and Meyer, 2015), social connections and networks (Caraka et al., 2021; Mailfert, 2007), customs and cultural values (Anderson, 2011). Then, this paper will conduct a study on a metaanalysis of papers that have been published in the Scopus database using the keyword "social vulnerability".

(C) 2021 Lifescience Globa 


\section{MATERIALS AND METHODS}

\section{Data Collection}

In this study, publication data was taken from Scopus sources using the keyword "social vulnerability".

\section{Data Analysis}

To analyze frequently occurring keywords, the step most crucial is to measure how often words appear together relative either how often they appear separately. Besides, the correlation between words. Regarding text, the correlation between words is measured in binary form - words appear together or not. The common measure for such binary correlation is the coefficient $\alpha$ in Table 1 and $\mathrm{Eq}(1)$

Table 1: Co-Appearing Words

\begin{tabular}{|c|c|c|c|}
\hline & Has Word & No Word & Total \\
\hline \hline Has Word & $a_{11}$ & $a_{10}$ & $a_{1 .}$ \\
\hline No Word & $a_{01}$ & $a_{00}$ & $a_{0 .}$ \\
\hline Total & $a_{1}$ & $a_{.0}$ & $a_{\text {total }}$ \\
\hline
\end{tabular}

$\alpha=\frac{a_{11} a_{00}-a_{10} a_{01}}{\sqrt{a_{1} a_{0} a_{0} a_{.1}}}$

\section{RESULTS AND DISCUSSION}

\section{What is Vulnerability?}

Vulnerability is a condition of a community or society that leads to or causes the inability to face threats of danger. Vulnerability is the level of possibility of a disaster object consisting of the community, structure, service, or geographic area experiencing damage or disturbance as a result of the impact of the disaster or the tendency of an object to be damaged by the disaster (Djalante and Thomalla, 2012; Djalante et al., 2020; Djalante, Shaw and DeWit, 2020). The level of a vulnerability is an important thing to know as one of the factors that influence the occurrence of natural disasters, disasters will become a hazard if they occur in vulnerable conditions. Outline, the level of vulnerability due to the occurrence of a disaster can be viewed from 3 aspects.

First, Physical vulnerability describes the estimated level of damage to the physical if there are certain dangerous factors (Douglas, 2007). Looking at various indicators as follows: presentation of built-up areas, building density, percentage of emergency construction buildings, electricity networks, road length ratios, telecommunication networks, and railways. Second, social vulnerability shows the estimated level of vulnerability to the safety of life or health of the population in case of danger (Cutter, Boruff, and Shirley, 2003; Flanagan et al., 2011). From several indicators, including population density, population growth rate. Then, Economic vulnerability is describing the amount of loss or damage to economic activities, the economic process that occurs when there is a threat of danger (Briguglio et al., 2009; Bussire and Mulder, 2000; Guillaumont, 2009). Indicators that can be seen are the percentage of working households and poverty. In this study, the indicators used to measure the level of vulnerability are based solely on physical vulnerability. Indicators in measuring physical vulnerability are indicators of housing density, availability of public facilities, and critical facilities. Social vulnerability refers to the socioeconomic and demographic factors that affect the resilience of communities (Flanagan et al., 2020). SoVI measured social inequality and space gaps as dimensions of social vulnerability (Kaban et al., 2019).

\section{A Global Overview on Social Vulnerability}

As a result, we found 29.468 documents. It is worth noting that the keyword used "social vulnerability" is deliberately very general to broaden the overall picture of the research field under consideration but focused on high-quality journals. Figure 1 shows the number of social vulnerability publications over the 52 years; the time interval starts in 1969 (1 publication) and ends with the 3007 publications already available online in November 2020. It can be noted that from 2008 to the year 2020 there is an increasing trend of publications. Table 2 shows the sources from which the publications were taken and the total number of publications over the years; It shows that the Plos One 253 articles, Social Science and Medicine 248 articles, Sustainability Switzerland 206 articles. For more details, the readers can refer to the Table. The distribution frequency of articles, as presented in Figure 2 and Figure 3, indicates the journals dealing with the topic and related issues. Between 2007 and 2019, it is possible to notice a significant growth in the number of publications on the topic.

As for the affiliation, in the selected sample, it was identified that the Universidade de Sao Paulo - USP is the most productive university with 320 papers, followed by the King's College London with 309 


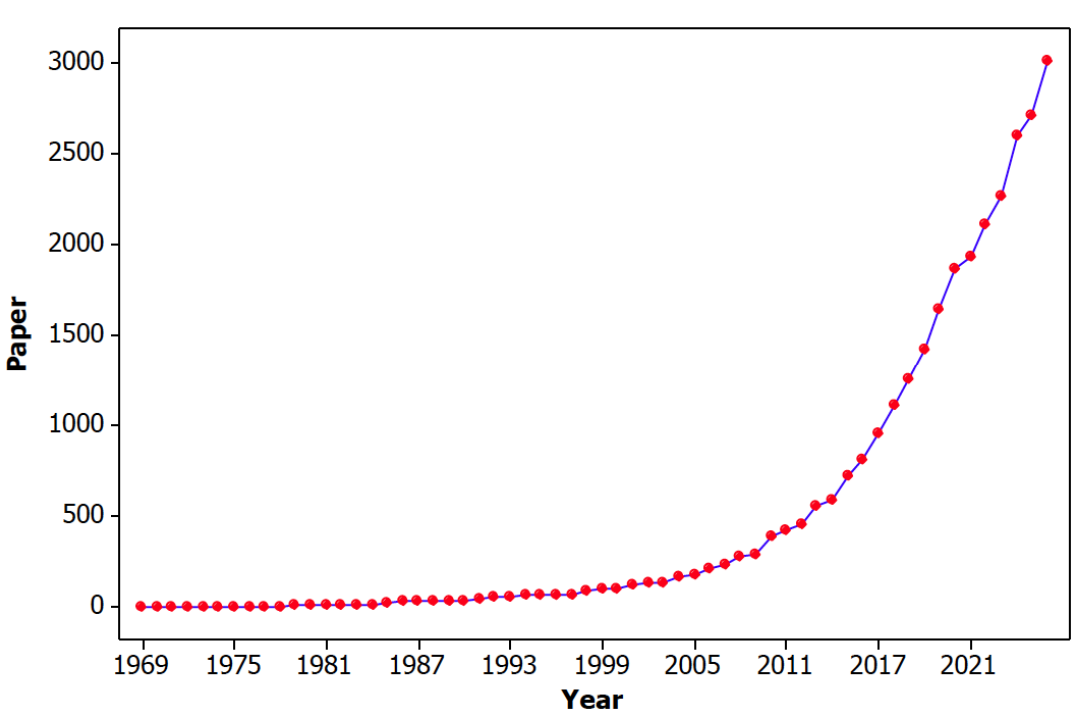

Figure 1: Publication of Paper Related to Keyword 'Social Vulnerability'.

Table 2: Top 48 Journal (Based on Mean Number of Paper=48)

\begin{tabular}{|c|c|}
\hline SOURCE TITLE & Paper \\
\hline Plos One & 253 \\
\hline Sustainability Switzerland & 206 \\
\hline Natural Hazards & 188 \\
\hline International Journal Of Disaster Risk Reduction & 154 \\
\hline $\begin{array}{c}\text { Lecture Notes In Computer Science Including Subseries Lecture Notes In Artificial Intelligence And Lecture Notes In } \\
\text { Bioinformatics }\end{array}$ & 144 \\
\hline Global Environmental Change & 136 \\
\hline Ciencia E Saude Coletiva & 113 \\
\hline BMC Public Health & 98 \\
\hline Journal Of Affective Disorders & 98 \\
\hline Psychiatry Research & 96 \\
\hline Psychological Medicine & 94 \\
\hline Ecology And Society & 81 \\
\hline International Journal For Equity In Health & 81 \\
\hline Iop Conference Series Earth And Environmental Science & 78 \\
\hline Regional Environmental Change & 75 \\
\hline Encephale & 73 \\
\hline
\end{tabular}




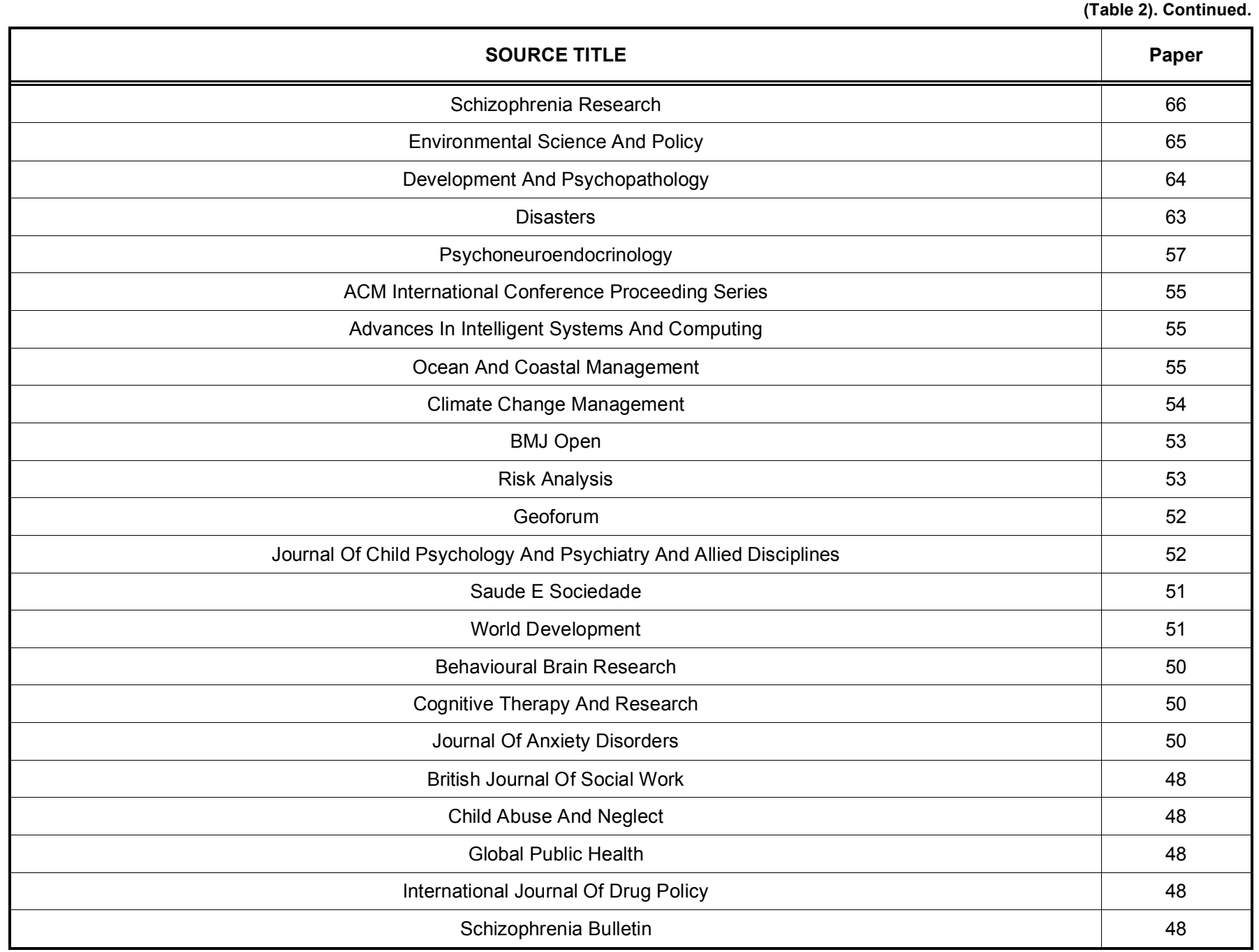
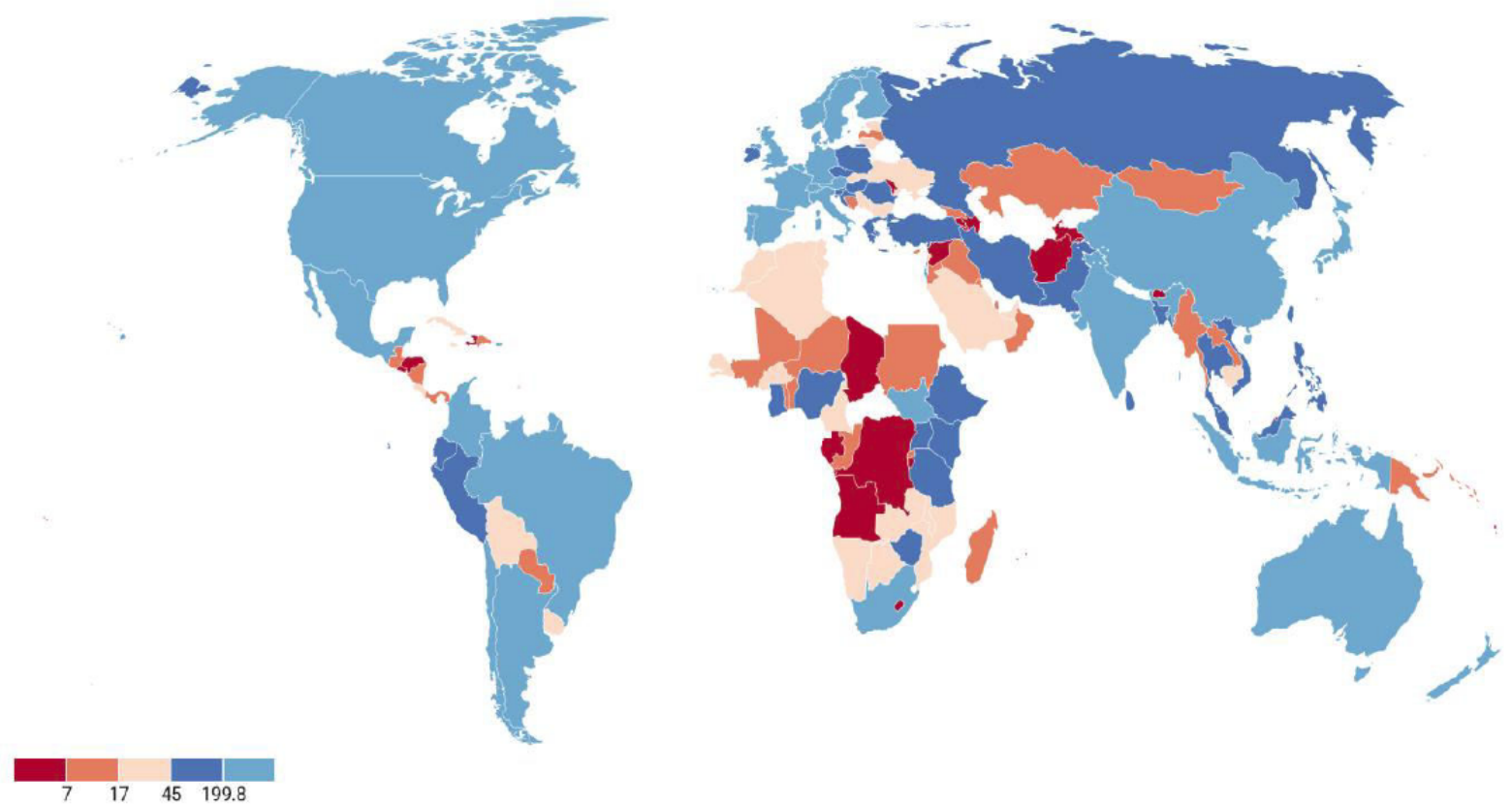

Figure 2: Distribution Frequency of Articles, Based on Quantile Equal Count. 

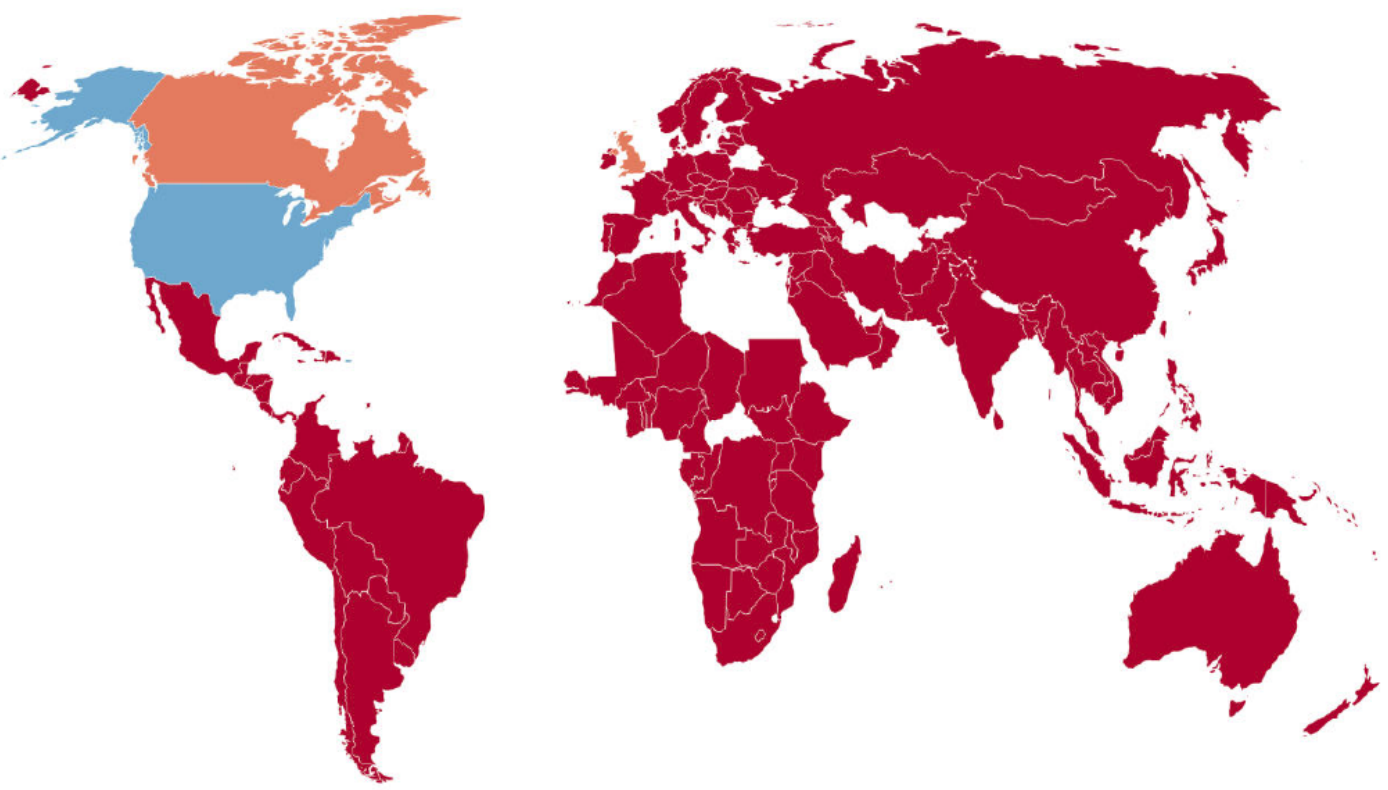

1881376056397518

Figure 3: Distribution Frequency of Articles, Based on Count.

Table 3: Top 53 (Based on Mean Number of Paper=107)

\begin{tabular}{|c|c|}
\hline AFFILIATION & Number Paper \\
\hline Universidade de Sao Paulo - USP & 320 \\
\hline King's College London & 309 \\
\hline University of Toronto & 292 \\
\hline Columbia University in the City of New York & 271 \\
\hline University College London & 270 \\
\hline The University of British Columbia & 264 \\
\hline McGill University & 242 \\
\hline University of California, Los Angeles & 211 \\
\hline University of Melbourne & 201 \\
\hline Inserm & 200 \\
\hline University of New South Wales UNSW Australia & 199 \\
\hline Harvard Medical School & 197 \\
\hline University of Michigan, Ann Arbor & 197 \\
\hline The University of North Carolina at Chapel Hill & 193 \\
\hline Arizona State University & 188 \\
\hline University of Oxford & 187 \\
\hline University of Washington, Seattle & 171 \\
\hline CNRS Centre National de la Recherche Scientifique & 169 \\
\hline Fundacao Oswaldo Cruz & 168 \\
\hline Yale University & 153 \\
\hline The University of Queensland & 148 \\
\hline Chinese Academy of Sciences & 146 \\
\hline
\end{tabular}


(Table 3). Continued.

\begin{tabular}{|c|c|}
\hline University of California, San Francisco & 146 \\
\hline University of East Anglia & 144 \\
\hline Monash University & 144 \\
\hline The University of Sydney & 142 \\
\hline Johns Hopkins Bloomberg School of Public Health & 141 \\
\hline Pennsylvania State University & 139 \\
\hline Harvard University & 131 \\
\hline University of Colorado Boulder & 125 \\
\hline University of Groningen & 125 \\
\hline University of Cambridge & 125 \\
\hline University of Montreal & 123 \\
\hline University of Cape Town & 122 \\
\hline Stanford University & 121 \\
\hline VA Medical Center & 113 \\
\hline Emory University & 112 \\
\hline Universidad Nacional Autónoma de México & 112 \\
\hline University of Wisconsin-Madison & 111 \\
\hline University of KwaZulu-Natal & 110 \\
\hline University of Leeds & 109 \\
\hline University of Witwatersrand & 107 \\
\hline University of Ottawa, Canada & 107 \\
\hline
\end{tabular}

scientific contributions and the University of Toronto with 292 articles. Meanwhile, Table 3 highlights the first 10 papers (with the total number of citations) ranging from 1821 to 5694 and Field-Weighted Citation Impact 3.20 to 41.88. Meanwhile, Field-Weighted Citation Impact $(\mathrm{FWCl})$ is the ratio of the total citations received by the denominator's output, and the total citations that would be expected based on the average of the subject field. To Scopus database, it is sourced directly from SciVal (Schneider et al., 2017; James et al., 2019)

It can be seen that although there are numerous specialist journals on Social vulnerability, the most cited papers have been published mainly in Social vulnerability journals and not necessarily on Social vulnerability. This phenomenon demonstrates that 


\section{Table 4: Most Cited Paper}

\begin{tabular}{|c|c|c|c|c|c|}
\hline Authors & Title & Year & Source title & Cited by & $\mathrm{FWCl}$ \\
\hline $\begin{array}{l}\text { Albert, Jeong and Barabási, } \\
(2000)\end{array}$ & $\begin{array}{l}\text { Error and attack tolerance of } \\
\text { complex networks }\end{array}$ & 2000 & Nature & 5624 & 12.51 \\
\hline (Steele and Aronson, 1995) & $\begin{array}{c}\text { Stereotype Threat and the } \\
\text { Intellectual Test Performance of } \\
\text { African Americans }\end{array}$ & 1995 & $\begin{array}{l}\text { Journal of Personality } \\
\text { and Social Psychology }\end{array}$ & 3965 & NA \\
\hline (Bishop et al., 2004) & $\begin{array}{l}\text { Mindfulness: A proposed } \\
\text { operational definition }\end{array}$ & 2004 & $\begin{array}{l}\text { Clinical Psychology: } \\
\text { Science and Practice }\end{array}$ & 2732 & 11.16 \\
\hline Smit and Wandel, (2006) & $\begin{array}{c}\text { Adaptation, adaptive capacity, and } \\
\text { vulnerability }\end{array}$ & 2006 & $\begin{array}{l}\text { Global Environmental } \\
\text { Change }\end{array}$ & 2498 & 27.08 \\
\hline $\begin{array}{l}\text { Cutter, Boruff, and Shirley, } \\
(2003)\end{array}$ & $\begin{array}{l}\text { Social vulnerability to } \\
\text { environmental hazards }\end{array}$ & 2003 & Social Science Quarterly & 2284 & 11.52 \\
\hline Turner et al., (2003) & $\begin{array}{l}\text { A framework for vulnerability } \\
\text { analysis in sustainability science }\end{array}$ & 2003 & $\begin{array}{l}\text { Proceedings of the } \\
\text { National Academy of } \\
\text { Sciences of the United } \\
\text { States of America }\end{array}$ & 2171 & 3.20 \\
\hline Koob and Le Moal, (1997) & $\begin{array}{l}\text { Drug abuse: Hedonic homeostatic } \\
\text { dysregulation }\end{array}$ & 1997 & Science & 1821 & 8.34 \\
\hline
\end{tabular}

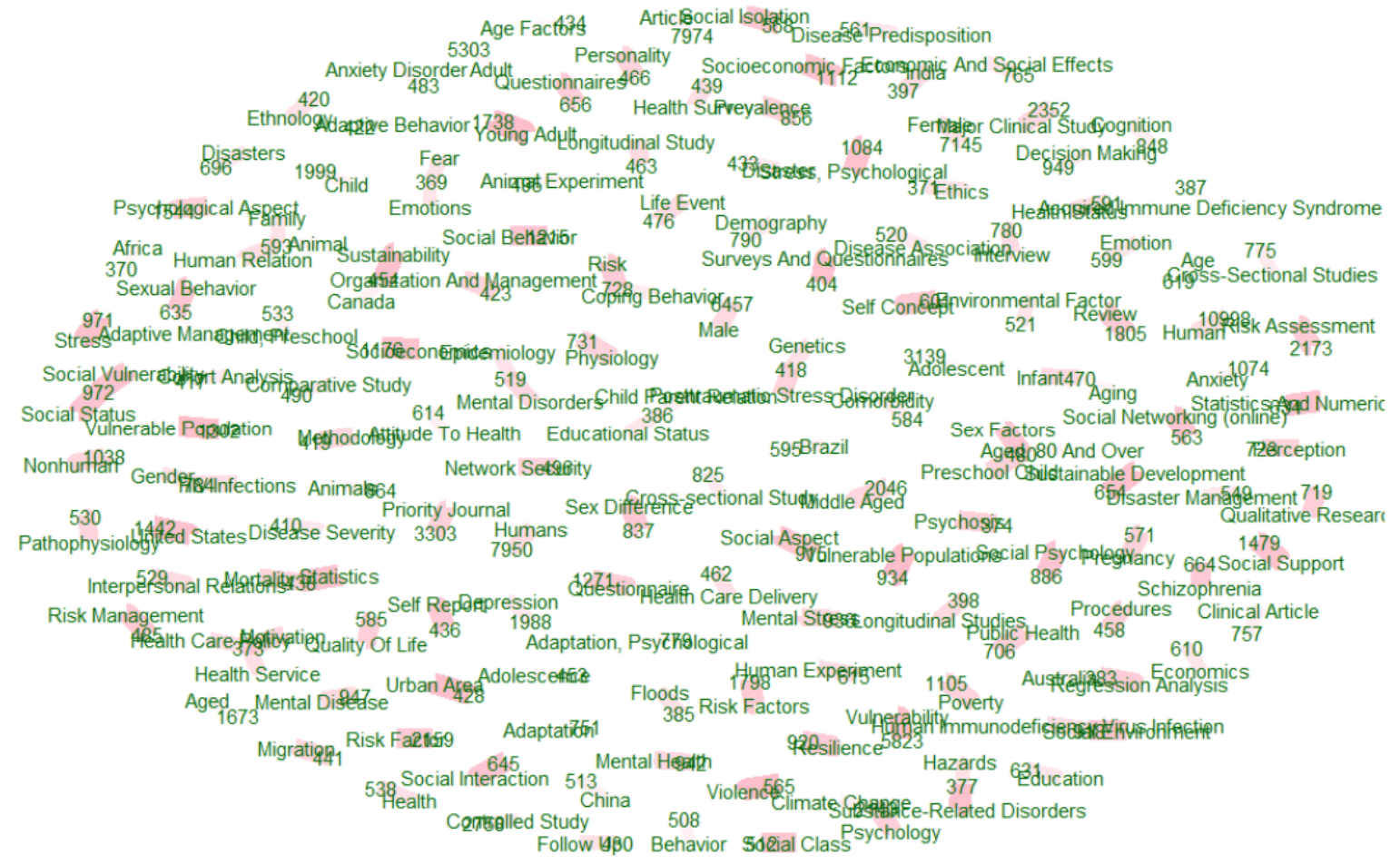

Figure 4: Cooccurrences within 3 words distance.

there is a constant growing consideration for the subject, this is apparent as indicated by the growing number of quotations per year on each article. Moreover, it can be seen that finance and the Social vulnerability and disaster are treated with different perspectives, and the elaboration plays a crucial in satisfying the research of the social vulnerability. 
Figure 4 explains that authors who publish papers using the keyword Social Vulnerability also use other keywords with the most Human/Humans (18948 articles), Sex and Gender (784 articles) Female (7145 articles), and Male (6457) This article deals with the impact of vulnerability on human life. For case studies, the most widely used keywords are the United States (1442 articles), Brazil (595 articles), China (513 articles), Canada (454 articles), India (397 articles), Australia (383 articles), Africa (370 articles). Untuk topik lainnya yang banyak dibahas antara lain adalah Climate change (2143 articles), Poverty (1105 articles) Socioeconomic and Socioeconomic factors (2288 articles), stress (971 articles), mental health and mental stress (1878 articles). Berbicara topik kesehatan, keyword yang populer digunakan adalah HIV Infections (784 articles), Schizophrenia (664 articles), health status (591 articles), Pregnancy (571 articles), Disease Predisposition (561 articles), Health (538 articles), Disease association (520 articles), Epidemiology (519 articles), Health care delivery (462 articles). For the most widely used method are following: Survey and questionnaire (1675 articles), cross-sectional (825 articles), interview (780 articles), qualitative research (719 articles), Statistics and Numerical data (634 articles), longitudinal study or longitudinal studies (861 articles), Statistics (438 articles), Cohort analysis (418 articles), respectively.

\section{CONCLUSION}

There are few application topics about Big data in papers with the keyword Social vulnerability. Currently, knowledge technology, and information have developed very rapidly. Increasingly sophisticated technology enables everyone to access and obtain information quickly, without recognizing regional boundaries and time constraints. This causes information to be valuable and indispensable for decision making. One of the pieces of information needed by developed countries is information about events. natural disasters. However, the information on natural disasters currently presented is still random, difficult to understand and its validity has not been proven. Even though natural disasters are unavoidable events, the impact of disasters can be reduced or minimized by identifying the causes of disasters and studying the disaster events that have happened by analyzing existing disaster data. Also, it is necessary to predict disasters that will occur in the future so that they can become indicators of natural disaster management that will occur. Processing data into easily understandable information has been done for various purposes. Natural disaster data processing is commonly done is using big data techniques ( $\mathrm{Yu}$, Yang, and Li, 2018), data mining (Zheng et al., 2013; Caraka et al., 2020; Cios et al., 2007), and loT (Kamruzzaman et al., 2017; Sakhardande, Hanagal, and Kulkarni, 2016). Big Data is an umbrella term for the explosion in the quantity and diversity of highfrequency digital data and it is not usually coming from traditional sources (Pramana et al., 2017; Cenggoro et al., 2019; Maroco et al., 2011). The cycle in the Big Data program is divided into four. First, prevention before the occurrence of a disaster; second, anticipate when there are indications of a disaster; third, the special response in the event of a disaster; fourth, recap the disaster data. What can be done properly is by remote sensing (Syahid et al., 2020; Van Westen, 2000).

\section{ACKNOWLEDGMENTS}

This study is fully supported by the National Research Foundation of Korea grants [NRF2019R1A2C1002408].

\section{CONFLICT OF INTEREST}

The authors declare no potential conflict of interest regarding the publication of this work. Also, ethical issues including plagiarism, informed consent, misconduct, data fabrication and, or falsification, double publication and, or submission, and redundancy have been completely witnessed by the authors.

\section{REFERENCES}

Adger, W. N. (2006) 'Vulnerability', Global Environmental Change, 16(3), pp. 268-281. https://doi.org/10.1016/j.gloenvcha.2006.02.006

Albert, R., Jeong, H. and Barabási, A. L. (2000) 'Error and attack tolerance of complex networks', Nature, 406(6794), pp. 378382.

https://doi.org/10.1038/35019019

Aldrich, D. P. and Meyer, M. A. (2015) 'Social Capital and Community Resilience', American Behavioral Scientist, 59(2), pp. 254-269. https://doi.org/10.1177/0002764214550299

Anderson, M. D. (2011) Disaster writing: The cultural politics of catastrophe in Latin America, Disaster Writing: The Cultural Politics of Catastrophe in Latin America. https://doi.org/10.5860/CHOICE.49-4337

Bishop, S. R. et al. (2004) 'Mindfulness: A proposed operational definition', Clinical Psychology: Science and Practice, 11(3), pp. 230-241.

https://doi.org/10.1093/clipsy/bph077

Briguglio, L. et al. (2009) 'Economic vulnerability and resilience: Concepts and measurements', Oxford Development Studies, 37(3), pp. 229-247. https://doi.org/10.1080/13600810903089893 
Bussire, M. and Mulder, C. (2000) 'Political instability and economic vulnerability', International Journal of Finance and Economics, 5(4), pp. 309-330. https://doi.org/10.1002/1099-1158(200010)5:4<309::AIDIJFE136>3.0.CO;2-I

Caraka, R. E. et al. (2020) 'Using Hierarchical Likelihood towards Support Vector Machine: Theory and Its Application', IEEE Access, 8, pp. 194795-194807. https://doi.org/10.1109/ACCESS.2020.3033796

Caraka, R. E. et al. (2021) 'Cluster Around Latent Variable for Vulnerability Towards Natural Hazards, Non-Natural Hazards, Social Hazards in West Papua', IEEE Access, 9, pp. 1972-1986. https://doi.org/10.1109/ACCESS.2020.3038883

Carreño, M. L., Cardona, O. D. and Barbat, A. H. (2007) 'A disaster risk management performance index', Natural Hazards, 41(1), pp. 1-20. https://doi.org/10.1007/s11069-006-9008-y

Cenggoro, T. W. et al. (2019) 'Features Importance in Classification Models for Colorectal Cancer Cases Phenotype in Indonesia', Procedia Computer Science, 157, pp. 313-320. https://doi.org/10.1016/j.procs.2019.08.172

Cios, K. J. et al. (2007) Data mining: A knowledge discovery approach, Data Mining: A Knowledge Discovery Approach. https://doi.org/10.1007/978-0-387-36795-8

Cutter, S. L., Boruff, B. J. and Shirley, W. L. (2003) 'Social vulnerability to environmental hazards.', Social science quarterly, 84(2), pp. 242-261. https://doi.org/10.1111/1540-6237.8402002

Djalante, R. et al. (2020) 'The ASEAN's responses to COVID-19: A policy sciences analysis', PsyArXiv, (February 2020), p. 368. https://doi.org/10.31234/osf.io/8347d

Djalante, R., Shaw, R. and DeWit, A. (2020) 'Building resilience against biological hazards and pandemics: COVID-19 and its implications for the Sendai Framework', Progress in Disaster Science.

https://doi.org/10.1016/j.pdisas.2020.100080

Djalante, R. and Thomalla, F. (2012) 'Disaster risk reduction and climate change adaptation in Indonesia', International Journal of Disaster Resilience in the Built Environment, 3(2), pp. 166-180. https://doi.org/10.1108/17595901211245260

Douglas, J. (2007) Physical vulnerability modelling in natural hazard risk assessment, Natural Hazards and Earth System Science. https://doi.org/10.5194/nhess-7-283-2007

Drake, P. (2016) Indonesia and the politics of disaster: Power and representation in Indonesia's mud volcano. Routledge. https://doi.org/10.4324/9781315525136

Flanagan, B. E. et al. (2011) 'A Social Vulnerability Index for Disaster Management', Journal of Homeland Security and Emergency Management, 8(1), pp. 1-24.

https://doi.org/10.2202/1547-7355.1792

Flanagan, B. E. et al. (2020) 'A Social Vulnerability Index for Disaster Management', Journal of Homeland Security and Emergency Management. https://doi.org/10.2202/1547-7355.1792

Guillaumont, P. (2009) 'An economic vulnerability index: Its design and use for international development policy', Oxford Development Studies, 37(3), pp. 193-228. https://doi.org/10.1080/13600810903089901

James, C. et al. (2019) 'CiteScore metrics: Creating journal metrics from the Scopus citation index', Learned Publishing, 32(4), pp. 367-374 https://doi.org/10.1002/leap.1246

Kaban, P. A. et al. (2019) 'Biclustering method to capture the spatial pattern and to identify the causes of social vulnerability in Indonesia: A new recommendation for disaster mitigation policy', Procedia Computer Science, 157, pp. 31-37. https://doi.org/10.1016/j.procs.2019.08.138
Kamruzzaman, M. et al. (2017) 'A study of loT-based post-disaster management', in International Conference on Information Networking, pp. 406-410. https://doi.org/10.1109/ICOIN.2017.7899468

Koob, G. F. and Le Moal, M. (1997) 'Drug abuse: Hedonic homeostatic dysregulation', Science, 278(5335), pp. 52-58. https://doi.org/10.1126/science.278.5335.52

Mailfert, K. (2007) 'New farmers and networks: how beginning farmers build social connections in France', in Tijdschrift voor economische en sociale geografie, pp. 21-31. https://doi.org/10.1111/j.1467-9663.2007.00373.x

Maroco, J. et al. (2011) 'Data mining methods in the prediction of Dementia: A real-data comparison of the accuracy, sensitivity and specificity of linear discriminant analysis, logistic regression, neural networks, support vector machines, classification trees and random forests', BMC Research Notes. https://doi.org/10.1186/1756-0500-4-299

Nasution, B. I. et al. (2020) 'Revisiting social vulnerability analysis in Indonesia: An optimized spatial fuzzy clustering approach', International Journal of Disaster Risk Reduction, 51(May), p. 101801. https://doi.org/10.1016/j.ijdrr.2020.101801

Pathirage, C. et al. (2012) 'Managing disaster knowledge: Identification of knowledge factors and challenges', International Journal of Disaster Resilience in the Built Environment https://doi.org/10.1108/17595901211263620

Pramana, S. et al. (2017) 'Big data for government policy: Potential implementations of bigdata for official statistics in Indonesia', in 2017 International Workshop on Big Data and Information Security (IWBIS), pp. 17-21. https://doi.org/10.1109/IWBIS.2017.8275097

Quarantelli, E. L. (1988) 'Disaster crisis management: A summary of research findings', Journal of Management Studies, 25(4), pp. 373-385. https://doi.org/10.1111/j.1467-6486.1988.tb00043.x

Sakhardande, P., Hanagal, S. and Kulkarni, S. (2016) 'Design of disaster management system using loT based interconnected network with smart city monitoring', in 2016 International Conference on Internet of Things and Applications, IOTA 2016, pp. 185-190. https://doi.org/10.1109/IOTA.2016.7562719

Schneider, M. et al. (2017) 'Feasibility of common bibliometrics in evaluating translational science', Journal of Clinical and Translational Science, 1(1), pp. 45-52. https://doi.org/10.1017/cts.2016.8

Schulz, R. and Beach, S. R. (1999) 'Caregiving as a risk factor for mortality: The caregiver health effects study', Journal of the American Medical Association, 282(23), pp. 2215-2219. https://doi.org/10.1001/jama.282.23.2215

Siagian, T. H. et al. (2014) 'Social vulnerability to natural hazards in Indonesia: driving factors and policy implications.', Natural Hazard, 70(2), pp. 1603-1617. https://doi.org/10.1007/s11069-013-0888-3

Smit, B. and Wandel, J. (2006) 'Adaptation, adaptive capacity and vulnerability', Global Environmental Change, 16(3), pp. 282292. https://doi.org/10.1016/j.gloenvcha.2006.03.008

Steele, C. M. and Aronson, J. (1995) 'Stereotype Threat and the Intellectual Test Performance of African Americans', Journal of Personality and Social Psychology, 69(5), p. 797. https://doi.org/10.1037/0022-3514.69.5.797

Syahid, L. N. et al. (2020) 'Determining Optimal Location for Mangrove Planting Using Remote Sensing and Climate Model Projection in Southeast Asia', Remote Sensing, 12(22), pp. 1-29. https://doi.org/10.3390/rs12223734 
Turner, B. L. et al. (2003) 'A framework for vulnerability analysis in sustainability science', Proceedings of the National Academy of Sciences of the United States of America, 100(July), pp. 8074-8079.

https://doi.org/10.1073/pnas.1231335100

Van Westen, C. (2000) 'Remote sensing for natural disaster management', International Archives of the Photogrammetry, Remote Sensing and Spatial Information Sciences - ISPRS Archives, 33(B7/4 PART7), pp. 1609-1617.
Yu, M., Yang, C. and Li, Y. (2018) 'Big data in natural disaster management: A review', Geosciences (Switzerland), 8(5), p. 165.

https://doi.org/10.3390/geosciences 8050165

Zheng, L. et al. (2013) 'Data mining meets the needs of disaster information management', IEEE Transactions on HumanMachine Systems, 43(5), pp. 451-464. https://doi.org/10.1109/THMS.2013.2281762

Received on 03-01-2021

Accepted on 28-01-2021

Published on 04-03-2021

https://doi.org/10.6000/1929-4409.2021.10.71

(C) 2021 Toharudin et al.; Licensee Lifescience Global.

This is an open access article licensed under the terms of the Creative Commons Attribution Non-Commercial License (http://creativecommons.org/licenses/by-nc/3.0/) which permits unrestricted, non-commercial use, distribution and reproduction in any medium, provided the work is properly cited. 